\title{
THE INFLUENCES OF LEADERSHIP COMMITMENT, HEALTH FACILITIES, HUMAN RESOURCE QUALITY AND COMMUNITY PARTICIPATION ON THE PERFORMANCE OF HEALTH SERVICES AT THE COMMUNITY HEALTH SERVICE CENTRE IN BOGOR REGENCY, INDONESIA
}

\author{
Susi Juniar \\ Ph.D Candidate, University of Satyagama, Jakarta-Indonesia
}

Tjahja Supriatna

Professor of Public Administration, Institute of Governance of Home Affairs, Indonesia

Jossy Adiwisastra

Professor of Public Policy field of Government Science, University of Pajajaran, Bandung-Indonesia

\author{
Dewi Sulistyani \\ Senior Lecturer, University of Satyagama, Jakarta-Indonesia \\ DOI: $10.31364 / \mathrm{SCIRJ} / \mathrm{v} 7 . \mathrm{i7} .2019 . P 0719671$ \\ http://dx.doi.org/10.31364/SCIRJ/v7.i7.2019.P0719671
}

\begin{abstract}
The objective of this study is to analyze the influence of leadership commitment, health facilities, human resources quality and community participation on the performance of health services at the Community Health Service Centre (locally called Puskemas) in Bogor regency, Indonesia. This study used quantitative method, namely, multiple regression analysis. The number of sample collected by using Slovin Formula was 350 respondents. The instrument to collect the data was by using questionnaires. The study found that leadership commitment, health facilities, and human resources quality have significant influenced partially on the performance of health services at the Community Health Service Center in Bogor Regency, Indonesia. Of these four variables, it was found that health facilities and the leadership commitment were found to have positive influence on the performance of health services at the Community Health Service Center in Bogor Regency. This suggests that serious attention to improve leadership commitment and health facilities in the community health services center in Bogor Regency is a must. If not, the performance of health services at the Community Health Services Center will not be effective. Thus, much remain to be done by the regional government as well as by the central government of Indonesia.
\end{abstract}

Key words: Leadership commitment, Health Facilities, Human Resource Quality, Community Participation, the performance of health services, and Community Health Services Center.

\section{INTRODUCTION}

In the era of globalization today, any organizations or institutions are required to make adjustments in all matters. Of the many organizations, the Community Health Service Center or locally called as Puskesmas is one of the public organizations that needs to improve the quality of health services. The importance of the improvement of health services is partly to attain a higher community satisfaction index as a benchmark for assessing the quality of community health service center. This can be done in the forms of the improvement of leadership commitment, health facilities, human resource quality and community participation to name a few.

The importance of leadership commitment, for instance, is to develop and empower all organizational resources to achieve goals, and to create a conducive and working atmosphere. By having leadership commitment, the organization can be well-managed and able to achieve the organizational goals. According to Davis (2010), there are four main characteristics of leadership success in organizations, namely: (1) Intelligence; (2) Social maturity and broad social relations; (3) Self motivation and encouragement of achievement; and (4) Human relations attitudes. 
The importance of leadership commitment in improving the health service performance of the Community Health Service Centre is simply because the Community Health Center (Puskesmas) has a strategic role in improving the health of the community. This condition will further improve the productivity of the community. For this reason, the Community Health Service Center (Puskesmas) are required to provide quality services, satisfy their patients in accordance with the established standards operation procedure and can reach all levels of society (Ministry of Health, 2014).

The present condition of the performance of health services given by the community health services center, however, is still far from the communities' expectations. Complaints that are often heard from the public relate to the quality of government apparatus, rigid bureaucracy, unfriendly behavior of the officials, and low performance of employees in providing better services (Rosidah, 2013). Due to these reasons, this study aims to examine the influence of leadership commitment, health facilities, human resource quality and community participation partially and jointly on the Performance of Health Services, by taking into account the Community Health Service Center in Bogor Regency as a case study. By taking this study, it is expected the government is able to formulate better policy solution to improve the performance of health services of the Community Health Service Center in Bogor Regency.

\section{LITERATURE REVIEW}

The influence of leadership commitment on the performance of health services has been advanced in the literature. According to Kartono (2004: 33), leader is a person who has skills and strengths at least in one field, so as she/he is able to influence others to carry out certain activities in order to achieve one or several goals. There are three elements that become role models in leadership, namely, a group of people, power, influence, and the ability to use those three elements and recognize that abilities are related to values (Bangun, 2008: 132).

Whilst commitment, according to Tjokroamidjojo (2001: 48) is a situation where someone wants to unite in a "suitable" position, even though sometimes it is contrary to his/her conscience. When someone makes a commitment with the public, there is a tendency to be more extreme on himself and think about the design implications of the behavior that he wants to display. This means that commitment makes people more responsive and has messages that contain hopes of a positive reputation for themselves. In other words, there is a desire to get more confidence in the opinions of different people.

Further, Aranya \& Ferris (2004: 1) define leadership commitment is an agreement or attachment to doing something best in a particular organization or group. There are "ten leadership commitments expected from each leader, namely, (1) Looking for Challenging Opportunities, (2) Daring to Try and Willing to Take the Risk, (3) Leading the Future, (4) Fostering Equality of Vision, (5) Raising Collaboration, (6) Strengthening Partners, (7) Demonstrating Exemplary, (8) Planning for Gradual Success, (9) Respecting Each Individual's Role, and (10) Appreciating every success. These suggest that leadership commitment will greatly influence health service performance.

In terms the influence of facilities and infrastructures, Hamalik (2003: 23) defines facilities and infrastructure are all intermediary forms used by people to spread ideas, so that the idea can reach the recipient. Infrastructure in this case is related to access that is supportive and is an inseparable component of the implementation of regional autonomy in the field of infrastructure. Also, it includes access that supports efforts to improve performance and access related to policies and programs that will be pursued by the governments to meet resource needs by human beings reliably, professionally and adequately.

Some principles that must be given attention in managing facilities and infrastructure in the Community Health Service Center (Puskesmas) include: (1) Principles of achieving goals, (2) Principles of Efficiency, (3) Administrative Principles, and (4) Principle of Similarity. While the purpose of management of health service facilities is: (1) to strive for the provision of health service facilities and infrastructure through careful planning and careful procurement systems, so that health services center will have good facilities and infrastructure, in accordance with health service needs, and with efficient funds, (2) to strive for the use of facilities and infrastructure services properly and efficiently, and (3) to keep maintaining health service facilities and infrastructures, so that they are always ready to be used.

The influence of human resources quality on the performance of health services has also been advanced in the literature. According to Lukman (2000: 7), quality is anything that is capable of meeting customer needs or needs (meeting the needs of customers). Whilst Silalahi (2000: 2) defined resource management includes planning to prevent excessive use of labor or below the level of labour utilization to achieve optimization of development work to ensure sufficient labor reserves that are skilled in interpersonal relations to ensure effective activities and industrial relations to realise participatory management and semi-trained utilization. 
Futhermore, Hasibuan (2001: 76) defined the development of human resources as an effort to improve the ability of technical, theoretical, conceptual and moral of individual in accordance with the needs of work / position through education and training. According to Bambang Wahyudi (2001: 97), the steps that must be taken in carrying out the development of human resources begin with an assessment of the work performance of each individual in the organization, so that it will be known with certainty of the quality of human resources held for a certain period. By appraising the performance of individual works, the possibility of developing human resources in the education and training program can be known, as well as through career development programs. In addition to that, Moenir (2000: 16) suggets that quality can also be interpreted as conformity with requirements, conformity with the user or free from damage / defects. Hence, by having quality of human resources, the performance of health services can be improved.

Finally, Siagian (2001: 324) defined participation in principle has the same meaning and connotation with participation, namely taking part or role in it. Whereas, according to Mardiasmo (2002: 26), community participation is defined as "processes, methods, means for citizens, especially the poor and marginal groups to be involved and contribute to controlling resources (allocation) through various public policy making processes that directly affect their lives.

However, in terms of the benefir of community participation, Indra (2003: 268) argues there are three benefits of community participation in policy making, namely: (1) The creation of better public policies, (2) Increased citizen trust in the executive and legislative branches, and (3) Resource efficiency. The main purpose of participation, according to Muhadjir (2004: 141), is to bring together all the same and different interests in a process of formulating and determining policies (decisions) proportionally to all parties involved and affected by the policy that will be determined in it. The involvement of the public in the process of determining policy is an effective way to accommodate various diverse interests. Public participation manifested in participatory planning can bring substantial benefits. This is because public decisions taken will provide a sense of satisfaction and strong public support for a development process. Therefore, community participation is very important factor in improving the quality of service. This is because community participation aims to bring together all the same and different interests in a process of formulating and determining policies proportionally to all parties involved and affected by the policy that will be determined in it.

\section{RESEARCH METHODS}

This study used explanatory quantitative approaches. Method used to collect the data is by undertaking field observation, interview and by distributing questionnaires to the sample respondents. In addition to the above primary data, the secondary data were collected by using web search and other relevant literature. The sample was chosen by applying a stratified proportional random sampling technique. The number of sample collected using Slovin formula was 350 respondents. These respondents include the staff of the community health service center, patient families and communities around the community health service center (Puskemas) located in Bogor Regency, West Java Province. The data collected was then analysed by using the multiple regression analysis. The variables under estimation is the performance of health services as the dependent variable (Y), while the independent variables are leadership commitment (X1), health facilities (X2), Quality of Human resources (X3) and Community participation (X4). The model can be written statistically as:

$$
\mathrm{Y}=\mathrm{a}+\mathrm{b} 1 \mathrm{X} 1+\mathrm{b} 2 \mathrm{X} 2+\mathrm{b} 3 \mathrm{X} 3+\mathrm{b} 4 \mathrm{X} 4+\mathrm{e} .
$$

$$
\begin{aligned}
\text { Where } \mathrm{Y} & =\text { the performance of health services } \\
\mathrm{X} 1 & =\text { leadership commitment } \\
\mathrm{X} 2 & =\text { Health facilities } \\
\mathrm{X} 3 & =\text { Quality of Human Resources } \\
\mathrm{X} 4 & =\text { Community participation } \\
\mathrm{a} & =\text { intercept } \\
\mathrm{b} 1 \ldots \mathrm{b} 4 & =\text { coefficients } \\
\mathrm{e} & =\text { error terms }
\end{aligned}
$$

\section{RESULTS AND DISCUSSION}

\section{Validity and Reliability Tests}

It should be noted that before the above model was estimated partially and jointly, both validity and reliabilty of the indicators of all variables were tested. The validity of indicators were tested by examining whether or not the value of $r$ calculated is greater than $r$ table. While the reliability of indicators of all variables were tested by examining whether or not the alpha Cronbach is greater than $r$ table. 
The study found that all indicators of leadership commitment, for instance, are valid because the value of $r$ counted was greater than $r$ table. Statement of indicator with the highest value of validity was the fifth statement of planning indicator $(0.640)$, followed by the thirteenth statement of cooperation indicator $(0.633)$ and the fourteenth statement of success indicators (0.620). This means that these indicators have a dominant influence on health service performance $(\mathrm{Y})$. The lowest value of validity is $\mathrm{t}$ he sixth statement of situation indicator with a validity value of 0.252 . This means that special attention is needed to the situation indicators. In terms of the reliability test, all indicators were found to be reliable since the alpha Cronbach $(\alpha)$ is greater than $r$ table.

For indicators of the health facility, the result of the validity test of all indicators are also valid since the value of $r$ counted is greater than $r$ table. The statement with the highest validity value is the fifth statement of the certification indicator (0.637), followed by the fifteenth statement of treatment (0.617) and the fourteen statement of usage indicators (0.616). This means that these indicators have a dominant influence on health service performance (Y). The lowest value of validity is the sixth statement of the indicator of sanitation of space and building with a validity value of (0.216). This means that special attention is needed to these indicators of sanitation of space and buildings. The reliability test of all indicators are reliable because of the value of alpha Cronbach $(\alpha)$ is greater than r table $(0.720>0.1044)$.

Futher, in terms of human resources quality, the results of the validity test of all indicators were valid because the value of $r$ counted was greater than $r$ table. The statement with the highest value of validity is the fifth statement of the indicators of self-development (0.640), thirteenth statement of the indicators of job description (0.635), and the fourteenth statements of the indicators of participation (0.620). This means that these indicators have a dominant influence on health services performance (Y). The lowest value of validity is the sixth statements of the exemplary indicator with a validity value of (0.252). This means that special attention is needed to the exemplary indicators. However, the reliability test confirmed that all indicators are reliable as the value of alpha Cronbach $(\alpha)$ was greater than $r$ table $(0.720>0.1044)$.

Also, for community participation, the results of the validity test of all indicators are valid because the value of $r$ count is greater than $r$ table. Statement with the highest value of validity was the fifth statement of the indicator of identifying and making priority scale $(0.638)$, followed by the thirteenth statements of creating policy indicator (0.623), and the fifteenth statement of indicators of efficiency (0.618). This means that these indicators have a dominant influence on health service performance (Y). The lowest value of validity is the sixth statements of the indicator of developing and provides a response with a validity value of (0.245). This means that special attention is needed to indicators of developing and providing responses. In terms of the reliability test, all indicators are reliable because of alpha Cronbach $(\alpha)$ was greater than $r$ table $(0.720>0.1044)$.

\section{Ordinary Least Square (OLS) Assumptions Tests}

Like many statistical analysis, Ordinary Least Square (OLS) regression has underlying assumptions. These assumptions should not be violated to produce the best estimate. However, if some of these assumptions are violated there is a need to employ remedial measure or use other estimation methods to improve the results. These assumptions are the assumption of linearity, homoscedasticity, no auto correlation, normality of errors, and multicollinearity. Of these assumptions, there are four assumptions are examined excluding the assumption of independence (no autocorrelation) as the data collected in the study was not time series data.

The above OLS assumptions were examined. The study confirmed that there was no violation toward the assumptions (see Susi Yuniar, forthcoming). In terms of the normality errors assumption, for instance, by using Kolmogorov-Smirnov test it was found that there is a significance value of leadership commitment (X1) to the performance of health services (Y) since the value was 0.250 greater than 0.05 . Similarly, the health facility (X2) also significantly affect the performance of health services (Y) with the value of $0.396>0.05$. Also, for the influence of the quality of human resources (X3) on the performamnce of health services (Y) with the value of $0.246>0.05$ and for the community participation (X4) against the performance of health services (Y) with the value of $0.390>0.05$. In other words, the four independent variables were found to have normal distribution (Table 1).

Table 1

Normality test of the variables

\begin{tabular}{|l|l|l|l|l|l|l|}
\hline \multicolumn{6}{|l|}{ One-Sample Kolmogorov-Smirnov Test } \\
\hline \multicolumn{2}{|l|}{} & $\mathrm{X}_{1}$ & $\mathrm{X}_{2}$ & $\mathrm{X}_{3}$ & $\mathrm{X}_{4}$ & $\mathrm{X}_{1}, \mathrm{X}_{2}, \mathrm{X}_{3}, \mathrm{X}_{4}$ \\
\hline $\mathrm{N}$ & 350 & 350 & 350 & 350 & 350 \\
\hline $\begin{array}{l}\text { Normal } \\
\text { Parameters }\end{array}$ & Mean & 0.0000000 & $\begin{array}{l}0.000000 \\
0\end{array}$ & 0.0000000 & 0.0000000 & 0.0000000 \\
\cline { 2 - 7 } & Std. Deviations & 1.51049495 & $\begin{array}{l}1.353673 \\
17\end{array}$ & 1.51071156 & 1.34949563 & 1.34916148 \\
\hline
\end{tabular}




\begin{tabular}{|l|l|l|l|l|l|l|}
\hline $\begin{array}{l}\text { Most Extreme } \\
\text { Differences }\end{array}$ & Absolute & 0.250 & 0.396 & 0.246 & 0.390 & 0.388 \\
\cline { 2 - 7 } & Positive & 0.250 & 0.396 & 0.246 & 0.390 & 0.388 \\
\cline { 2 - 7 } & Negative & -0.156 & -0.310 & -0.155 & -0.306 & -0.306 \\
\hline Test Statistic & 0.250 & 0.396 & 0.246 & 0.390 & 0.388 \\
\hline Asymp. Sig. (2-tailed) & \multirow{2}{*}{$0.000^{\mathrm{c}}$} & $0.000^{\mathrm{c}}$ & $0.000^{\mathrm{c}}$ & $0.000^{\mathrm{c}}$ & $0.000^{\mathrm{c}}$ \\
\hline
\end{tabular}

Note : Leadership commitment $\left(\mathrm{X}_{1}\right)$,

Health facility $\left(\mathrm{X}_{2}\right)$,

Quality of human resources $\left(\mathrm{X}_{3}\right)$,

Community participation $\left(\mathrm{X}_{4}\right)$,

Source : Estimated from the survey collected data.

\section{Model Estimation and Hypotheses Testing}

As there was no violation toward the OLS assumptions, the results of the model were shown at Table 2. As can be seen from this Table, at least there are three independent variables that are partly influenced significantly the dependent variable. These three independent variables are the leadership commitment, health facilities and quality of human resources, while the community participation was found to be insignificantly affected the performance of health services. The significant effects of the variables of leadership commitment, health facilities and the quality of human resources on the health service performance were seen from both the estimated $t$ values as well as from the probability Alpha value. The $t$ values of these three independent variables were greater that the $t$ values in the statistical table of 1.960. Also, in terms of the probability values, these three independent variables have probability values less than 5 per cent. These indicate that the null hypothesis that said that leadership commitment, health facilities and the quality of human resources have no partly effects on the performance of health services were rejected. In other words, each of these three variables has significant effect on the performance of health services.

Unlike the three independent variables above, the independent variable of community participation has no significant effect on the performance of health services. This was shown from the estimated $t$ value and the probability value. The $t$ value of this variable was less than the $t$ table. Similarly, the probability value of this independent variable was than 5 percent (Table 2). This suggests that the null hypothesis that stated the community participation has no partly effect on the health performance were accepted.

Table 2

The Estimated Regression Results

\begin{tabular}{|c|c|c|c|c|c|c|}
\hline & \multirow[t]{2}{*}{ Model } & \multicolumn{2}{|c|}{$\begin{array}{l}\text { Unstandardized } \\
\text { Coefficients }\end{array}$} & $\begin{array}{l}\text { Standardized } \\
\text { Coefficients }\end{array}$ & \multirow[t]{2}{*}{$\mathrm{t}$} & \multirow[t]{2}{*}{ Sig. } \\
\hline & & B & Std. Error & Beta & & \\
\hline \multirow{5}{*}{1} & (Constant) & 1.956 & 0.865 & & 2.262 & 0.024 \\
\hline & Leadership commitment $\left(\mathrm{X}_{1}\right)$ & 0.266 & 0.043 & 0.260 & 6.124 & 0.000 \\
\hline & Health facilities $\left(\mathrm{X}_{2}\right)$ & 0.474 & 0.236 & 0.486 & 2.011 & 0.045 \\
\hline & Quality of human resources $\left(\mathrm{X}_{3}\right)$ & -0.191 & 0.097 & -0.195 & -1.970 & 0.050 \\
\hline & Community participation $\left(\mathrm{X}_{4}\right)$ & 0.422 & 0.219 & 0.433 & 1.924 & 0.055 \\
\hline
\end{tabular}

Source : Output SPSS 25 from data collected.

However, in terms of the joint effects of the four independent variables on the performance of health services, the study found that the four independent variables have significant effects on the performance of health services. This was shown from the estimated $\mathrm{F}$ value which is greater than $\mathrm{F}$ table. Also, in terms of the F probability value it was less than 5 percent (Table 3). This indicates that all the four independent variables jointly have significant effects on the health service performance. Thus, this indicates that the leadership commitment, health facilities, quality and human resources and the community participation have significant roles in improving the health service performance at the Community Health Services Center in Bogor Regency.

Table 3.

\begin{tabular}{|c|c|c|c|c|c|c|}
\hline \multicolumn{2}{|c|}{$\begin{array}{l}\text { ANOVA test } \\
\text { Model }\end{array}$} & \multirow{2}{*}{$\frac{\text { Sum of Squares }}{6845.533}$} & \multirow[t]{2}{*}{ Df } & \multirow{2}{*}{\begin{tabular}{r|} 
Mean Square \\
1711.383
\end{tabular}} & \multirow{2}{*}{$\frac{\mathrm{F}}{1331.225}$} & \multirow{2}{*}{$\frac{\text { Sig. }}{.000^{\mathrm{b}}}$} \\
\hline 1 & Regression & & & & & \\
\hline & Residual & 443.522 & 345 & 1.286 & & \\
\hline
\end{tabular}




\begin{tabular}{|l|l|l|l|}
\hline Total & 7289.054 & 349 & \\
\hline a. Dependent Variable: The performance of health services (Y) \\
\hline $\begin{array}{l}\text { b. Predictors: (Constant), community participation }\left(\mathrm{X}_{4}\right) \text {, quality of human resources }\left(\mathrm{X}_{3}\right) \text {, Health } \\
\text { facility }\left(\mathrm{X}_{2}\right) \text {, and leadership commitment }\left(\mathrm{X}_{1}\right)\end{array}$
\end{tabular}

Source : Estimated from the survey data collected.

In terms of the estimated regression model, as can be seen at Table 2 the estimated regression model is as follows.

$$
\hat{Y}=1.956+0.266 \mathbf{X}_{1}+0.474 \mathbf{X}_{2}-0.191 \mathbf{X}_{3}+0.422 \mathbf{X}_{4}
$$

From this regression model, it can be seen that health facilities has the largest coefficient, followed by community participation, leadership commitment and the quality of human resources. However, of these four variables, community participation as mentioned previously has no significant effect on the performance of health services. This is shown from the estimated $t$ value which less than the value of $t$ table. Also, it is from the probability value which is greater than 5 percent. The meaning of the coefficient of health facilities of 0.474 was that for every changes of 1 unit of health facilities, it will change the health services performance by 0.474 . Similarly, for every changes of 1 unit of community participation and leadership commitment, there will be changes on the health services performance by 0.422 and 0.266 respectively. However, changes of 1 unit of the quality of human resources will adversely or negatively changes the health service performance by 0.191 . The adverse effect of the quality of human resources on the health services performance may be due to the fact of the lack of quality of human resources in the community health center in Bogor Regency.

The coefficient determination of the estimated regression model or R adjusted square (R2) was found to be about 0.938 (Table 4). This indicates that the effect on the health service performance can be explained by 93.8 percent of leadership commitment, health facilities, quality of human resources and community participation. It is only about 6.2 percent of the effect on the health service performance can be explained by other variables that were not examined in this study.

Table 4.

The Coefficient Determination

\begin{tabular}{|l|c|c|c|c|}
\hline Model & $\mathrm{R}$ & $\mathrm{R}$ Square & $\begin{array}{c}\text { Adjusted } \mathrm{R} \\
\text { Square }\end{array}$ & Std. Error of the Estimate \\
\hline 1 & $0.969^{\mathrm{a}}$ & 0.939 & 0.938 & 1.134 \\
\hline $\begin{array}{l}\text { a. Predictors: (Constant), Community participation }\left(\mathrm{X}_{4}\right) \text {, quality of human } \\
\text { resources }\left(\mathrm{X}_{3}\right) \text {, Health facility }\left(\mathrm{X}_{2}\right) \text {, Leadership commitment }\left(\mathrm{X}_{1}\right)\end{array}$ \\
\multicolumn{2}{|l}{ b. Dependent Variable: The performance of health services $(\mathrm{Y})$} \\
\hline
\end{tabular}

Source: estimated from the survey data collected.

\section{The Implications of the Study}

The implications of this study are as follows. First, there is a need to increase the leadership commitment in promoting equitable, affordable, quality and equitable health services. Second, there is a need to improve the availability of health facilities and medical devices in the community health services center. Third, there is a need to improve quality of human resources by developing and optimizing health resources equitably. Fourth, there is a need to increase community participation by empowering communities, the private sector and the community in health development through regional, inter-regional, national and global cooperation. Finally, there is a need to increase the performance of health services by improving the management accountably, transparently and effectively in order to strengthen a responsible health decentralization. Detail of the implications of the study above is modeled at Figure1. 
Figure 1. Model of Health Service Center

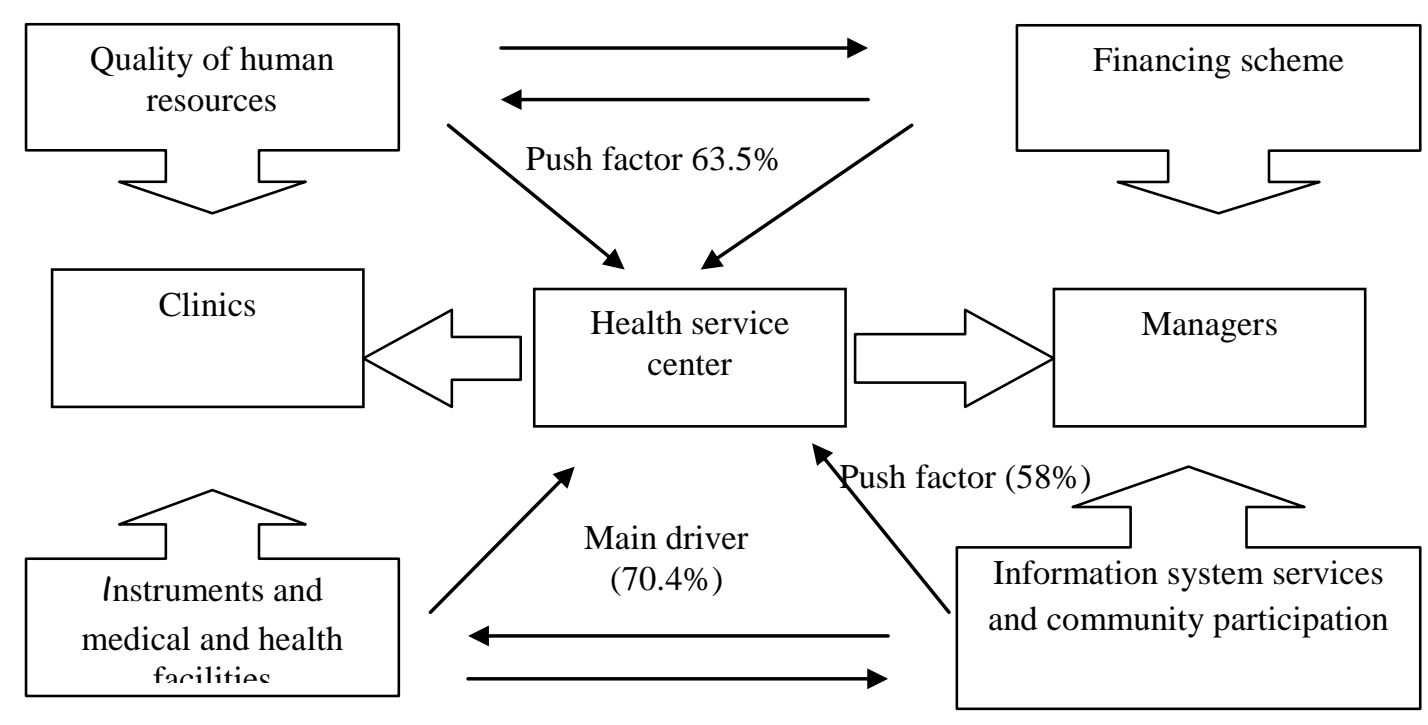

\section{CONCLUDING REMARKS}

This study found that leadership commitment, health facilities, quality of human resources, community participation jointly have significant effects on the performance of health services in the Community Health Service Center (Puskesmas) in Bogor District. However, the partial effect of each independent variable differs between one variable and another. The leadership commitment, health facilities and quality of human resources were found to be significant in influencing the performance of health services of Puskesmas in Bogor District, while the community participation showed insignificant effect on the performance of health services. Also note that the quality of human resources has adverse effect on the performance of health services.

The findings above suggest that serious attention to improve leadership commitment and health facilities in the community health services center in Bogor Regency is a must. If not, the performance of health services at the Community Health Services Center will not be effective. Thus, much remain to be done by the regional government of Bogor District as well as by the central government of Indonesia.

\section{REFERENCES}

[1] Ambar T. Sulistiyani dan Rosidah. 2013. Manajemen Sumber Daya Manusia. Cetakan. Pertama. Penerbit Graha Ilmu; Yogyakarta.

[2] Antoni, Chandra, \& Susanti.2016. Faktor-Faktor yang Mempengaruhi Struktur Modal\ Perusahaan Manufaktur di BEI. Jurnal Benefita, 78-94.

[3] Aranya \& Feriis.2004.Recxamination of Accountan Organization Profesional; Conflict.

[4] Bambang, Wahyudi, 2001, Teori Administrasi Publik, Gramedia Pustaka Utama; Jakarta.

[5] Bangun, Wilson.2008. Intisari Manajemen. PT. Refika Aditama; Bandung

[6] Davis, Keith, 2010. Organizational Behavior - Human Behavior at Work 13th. Edition

New Delhi: Mcgraw Hill Company.

[7] Hamalik,Oemar.2003.Manajemen Pengembangan Sarana Prasarana, PT. Remaja Rosda Karya; Bandung

[8] Hasibuan, Malayu, 2001, Manajemen Kinerja, Penerbit Bumi Aksara, Jakarta.

[9] Indra L.2003.Otonomi Daerah; Evaluasi dan Proyeksi, CV. Trio Rimba Persada; Jakarta.

[10] Kartini, Kartono.2004. Pemimpin dan Kepemimpinan. Abnormal Rajawali; Jakarta

[11] Kemenkes RI. Profil Kesehatan Indonesia tahun 2014. Kemenkes. RI; Jakarta

[12] Lukman.2000. Pengertian Kualitas.PT. Sumber Ilmu; Jakarta.

[13] Mardiasmo.2002.Partisipasi Masyarakat. CV. Sumber Ilmu;Surabaya.

[14] Moenir. 2000. Manajemen Pelayanan Publik. Jakarta: Bina Aksara

[15] Siagian, Sondang P 2001. Pengembangan Sumber Daya Manusia, Bumi Aksara; Jakarta.

[16] Silalahi, Bennet.2000.Manajemen Keselamatan dan Kesehatan Kerja, Cetakan Kedua, Institut Pendidikan dan Pembinaan Manajemen. PT. Binaman Pressindo;Jakarta.

[17] Susi Yuniar, forthcoming. Pengaruh Komitmen Kepemimpinan, Fasilitas Keseahtan, 
Kualitas Smber daya Manusia dan Partisipasi Masyarakat terhadap Kinerja Pelayanan Kesehatan di Kabupaten Bogor, Ph.D thesis, University of Satyagama, Jakarta.

[18]Tjokroamidjojo, Bintoro.2001.Pengantar Administrasi Pembangunan. Cetakan Ke-17, LP3ES; Jakarta. 